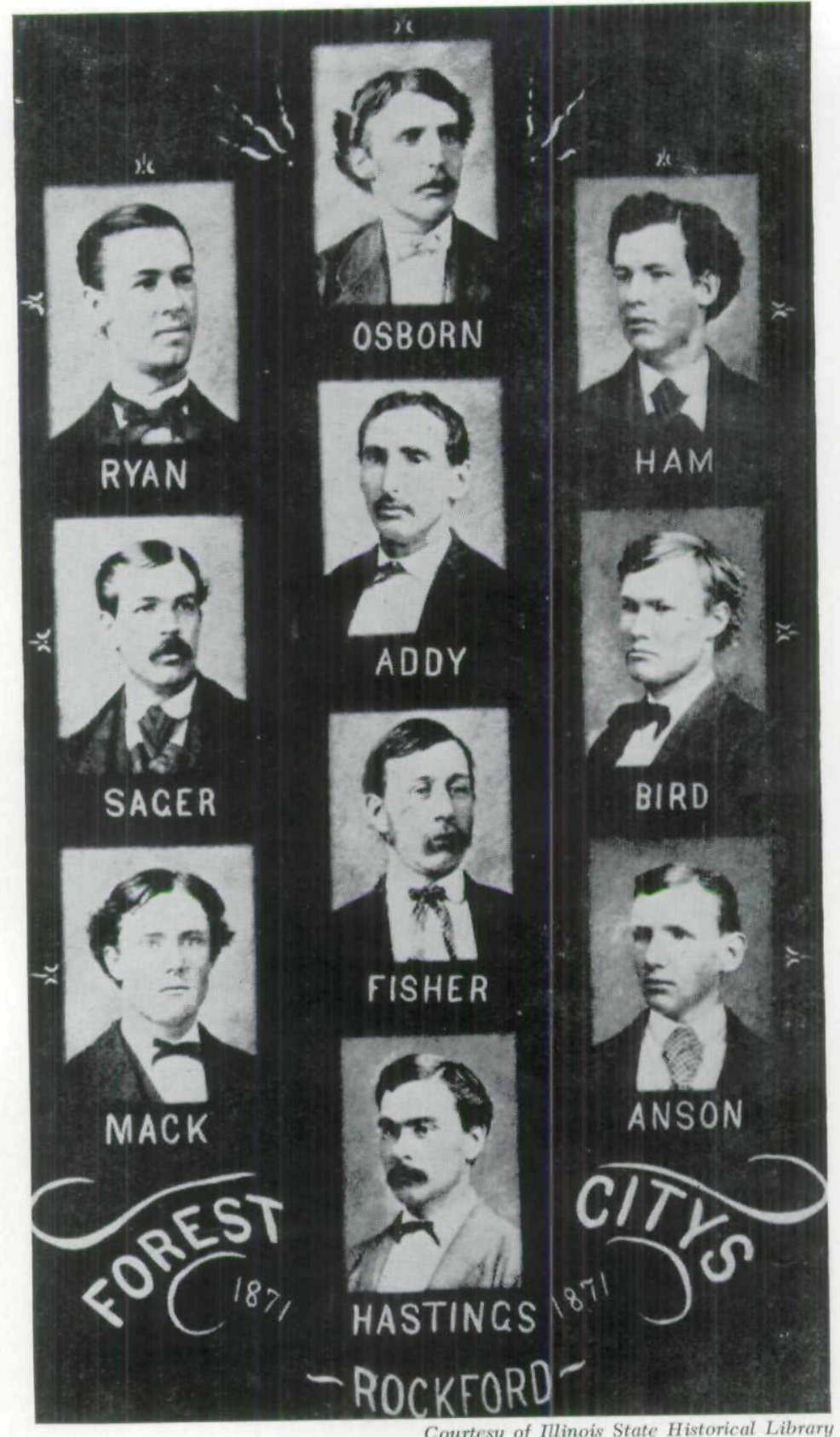

Courtesy of Illinois State Historical Library

ANSON'S FIRST YEAR AS A PROFESSIONAL

Signed With Rockford in 1871 


\section{"Cap" Anson's First Contract}

By Dr. Roger H. VAN Bolt

Illinois State Historical Library

Ever since the Civil war, baseball has been part and parcel of the sporting scene. Young men who show unusual ability in the game in high schools and colleges are enticed by fabulous offers to sign professional contracts. Those who accept become the "bonus babies" of the current season. A somewhat similar label was applied in 1871 to a gangling youth from Iowa who came to Rockford, Illinois, to play professional baseball - "The Marshalltown Infant." His first professional contract called for a salary of $\$ 66.66$ per month during the playing season. Thus began the illustrious career of Adrian Constantine Anson, better known as "Cap" Anson. It was twenty-seven years later that this blond giant completed the terms of his last contract.

Rockford in 1871 was a rather quiet and unassuming town of about 11,000 people. But it was known far and wide to baseball "cranks" (later they became "fans") as the home of the Forest City nine. The baseball club had been organized in 1865 under the presidency of H. H. ("Hi") Waldo, the local bookseller and erstwhile abolitionist. But the team's national reputation was not established until 1867. During that summer, the powerful Washington Nationals raised $\$ 5,000$ to tour the country. This aggregation of government clerks and college students won every game on the trip except one. Its lone defeat came at the hands of the Forest City nine. Rockford was too far west so the game was played in Chicago. The upstarts from the Illinois prairies, who were really to be a warm-up for a game the next day with the Chicago Excelsiors, were led by a seventeen-year-old youth from Byron, Illinois - Albert G. Spaulding, 
who pitched his team to a 29-23 victory. From that day, the team of amateurs from Rockford was to be reckoned with in the eyes of the enthusiasts of the game. An even greater day dawned in 1870 when the Forest Citys defeated the famous Cincinnati Red Stockings by a score of 12 to 5 .

It was not surprising that when the National Association of Professional Baseball Players was organized early in 1871, that Rockford was one of the nine original members of the league. Even before the season began the Forest City Club was in trouble. Its stars, Albert G. Spaulding, Fred Cone, and Roscoe Barnes were lured to Boston to play for the Red Stockings. Interest waned, and it was soon apparent that Rockford was no longer a baseball power. This first season of the professional baseball league ended with the Forest Citys being able to claim one dubious distinction: It was the first team to finish last in the history of the league - the original cellar team. This dismal showing brought a quick end to major league baseball in Forest City. From then on it was minor league territory.

Rockford's star had fallen, but its third baseman was just beginning to rise. The next season found him in Philadelphia. There he stayed until 1876 when he came to Chicago. Here he remained as first baseman and manager until 1898. "Baby" Anson became "Cap" Anson and finally "Old Anse" or "Pop." When he retired, his Chicago Colts were promptly labeled "The Orphans."

\section{Anson Achieved Distinction}

Anson's diamond achievements were many. First of all, he stayed around a long time - he was an active player in professional baseball for twenty-seven years. At the time of his retirement he was forty-seven years old. Cap was a hitter, too. His lifetime batting average was .339. Four times he led the National League and twice his average was over .400 . Always a strong finisher, he batted .302 in his last season at Chicago. 
Although he was not a flawless fielder, he could and did play any position well. His most disastrous experiences in the field came in the ill-fated world championships of 1885 . There were 100 errors - and 97 hits - in the seven games and Anson contributed his share. He booted four chances in each of the last two games. He has also been labeled the first great manager. His Chicago team won five world championships in his first six seasons. Then came a drought of fifteen years.

Six feet two, and 220 pounds, he was the dominating figure on the diamond. His nickname, "Cap," was more than a mere title. For example, he once chased the owner of the Chicago team, Spalding, off the field during an argument. Anse was the first to make use of the baselines as a coaching box, and when aroused, the New York Times reported that "he had a voice in his impassioned moments like a hundred bulls of Bashan." Always the colorful player, Cap was the pride of sports-writers and fans alike. He inspired Eugene Field to describe him poetically:

Lo! from the tribunes on the bleachers comes a shout,

Beseeching bold Ansonius to line 'em out;

And as Apollo's flying chariot cleaves the sky,

So stanch Ansonius lifts the brightened ball on high.

But Mr. Dooley's creator, Finley Peter Dunne, was not as kind in his word picture:

Capt. Anson marched to the bat to the music of rounds of applause, and found a basket of flowers at the home plate. Anson looked a trifle redder than usual, and with his blue suit and white stockings, might have gone to the top of the capitol building as an American flag. He struck out vigorously and the audience laughed him another shade redder.

Cap was not one to shrink from his critics, however. In later years when his age became a target, Anson appeared one afternoon in Boston with his chin adorned by white whiskers - he played errorless ball that day. 


\section{Actor and Politician in Later Years}

Off the diamond his exploits included the stage. He was the star of a baseball play called "The Runaway Colt," and also appeared in a slapstick vaudeville act during which he sang a song with others entitled "We're Ten Chubelin Tipperary Turks." His costume included green whiskers. As late as 1910 he could be seen on the New England circuits.

In 1905, Anson was swept into political office as City Clerk of Chicago. Although he was prominent in Democratic affairs for several years his record has long been forgotten. Only his statement when notified of his election seems to have survived. He told the press, "I'm just as pleased as if I'd won another penant." Baseball, not politics, was his game.

Business ventures in Chicago kept Anson busy in his later years. For a time he was a bottler of ginger beer. The product was so explosive, however, that he later reported that he feared to walk the streets lest he be pointed out as a purveyor of dynamite. Cap managed billiard parlors, bowling alleys, ice rinks, toboggan slides and golf courses. "Capt. Anson's indestructible score card" was another of his enterprises. In 1900, his memoirs appeared in the booksellers' stalls. It was not a distinguished work. These excursions were extracurricular activities for "Old Anse" for his heart was in baseball.

Before his death in 1922, Cap used to say that his epitaph was going to be: "Here lies a man who batted .300." Many years later Baseball's Hall of Fame was more eloquent. His plaque at Cooperstown, New York, reads: "the greatest hitter and greatest national league player-manager of the 19th century."

\section{First Contract at Rockford}

Although Adrian C. Anson played baseball around the world, he never forgot his first contract. "It was a fairly good salary for a ball player," he said, "and especially one who was only eighteen years old and a green country lad at that." Here is Cap's first pro- 
fessional contract which was recently acquired at the Illinois State Historical Library:

Memorandum of Agreement: made and entered into, this 31 day of March A. D. 1871, by and between John P. Manny, John C. Barbour, Henry W. Price, Hosmer P. Holland and Jerome C. Roberts ${ }^{1}$ of the City of Rockford, Illinois, party of the first part: and Adrian C. Anson of Marshalltown, Iowa, party of the second part:

Whereas divers residents of said city of Rockford, have associated themselves and contributed a common fund for the organization and maintenance of a first class base ball club, to be known and called "The Forest City Base Ball Club, of Rockford Illinois":

And whereas the said party of the second part, being desirous of playing in said Club: has represented to the party of the first part that he is a first class base ball player and possessed of the skill, and physically competent to play said game as a member of a first class club:

Now Therefore, this Agreement Witnesseth: That the said party of the second part, in consideration of the premises and of the promises and agreements of the party of the first part, hereinafter expressed, has, and does, covenant and agree, to and with said party of the first part, to play the game of baseball with said Forest City Base Ball Club, and in any position, he may be therein assigned by the Directors of said Club, for and during the season of A. D. 1871, to wit: from April 15 A. D. 1871, to and including October 15 A. D. 1871.

And in further consideration of the premises said party of the second part promises and agrees to keep and observe the following rules of conduct and discipline, viz:

To use his best efforts to advance the interests of said Club, by cheerfull, prompt and respectfull obedience of the Directions and requirements of the Directors thereof, or of any person by said Directors placed in authority over him, as well as the by laws of said Club:

To abstain from the use of alcoholic Liquors: unless medically prescribed, and to conduct himself, both off and on the Ball Ground, in all things like a gentleman.

To report promptly for duty at the grounds of the Club

${ }^{1}$ Manny was a wealthy manufacturer of knife sections for the Manny reapers. His royalties were reputed to have brought him an income of $\$ 60,000$ a year. Barbour was a dry goods merchant; Price manufactured boots, shoes and gloves; Holland was an attorney and partner ner of Manny; and Roberts had been a butter and egg dealer in Rockford for more than twenty years. 
for all games, and for practice at the hours designated there for by the officers of the Club, and upon the grounds, to abstain from profane language, Scuffling and light conduct, and to discourage the same in others.

To practice at least two and a half hours per day, on each and every practice day of the Club, and at all times both in games and at practice, to use his best endeavors to perfect himself in play, Always bearing in mind that the object in view in every game is to win.

And in further consideration of the premises said party of the second part promises and agrees that he will make, or procure to be made for him, or in any bet or wager upon the result of any game, or upon the playing of any members of the club, or upon anything connected with any game, in which said Forest City Club, may engage during the time of his engagement here under.

And in Consideration of the premises, said party of the first part promise and agree to pay said party of the second part the sum of Sixty six and two third $\left(\begin{array}{ll}\$ 66 & 2 / 3\end{array}\right)$ Dollars per month for each and every month of the time he may play with said Forest City Club, payable as follows: to wit: Sixty Six and two third (\$66 2/3) Dollars on the 1st day of June A. D. 1871, and sixty six and two third (\$66 2/3) Dollars on the first day of each and every month thereafter of the term of his employment, as aforesaid, the balance due to be fully paid on the 1st day of November A. D. 1871.

\section{A. C. ANSON}

\section{C. BARBOUR} HOSMER P. HOLLAND

Along with this Anson contract the Historical Library acquired the 1871 contract of Winfield Scott Hastings. He had evidently been with the team for several years and the Forest Citys agreed to pay him $\$ 100$ per month. He was twenty-three years old at the time but his baseball career was over at the age of thirty. From Rockford he went to Cleveland in 1872 , and after that he jumped from team to team, ending up in 1877 at Cincinnati. 


\section{Anson's Career Story}

Marshalltown's product, in the person of the greatest ball player the country has ever known, Capt. Adrian C. Anson, wrote and left to the world a lasting memoir in the publication of an interesting volume entitled "A Ball Player's Career."

Marshalltown watched for three generations the career of "Ada," as they called him, and the player's book dealt largely with early affairs in Marshalltown - the days when the place was a mere village of a few straggling homes. "The game at Marshalltown" was referred to at length in the exhaustive story of the life of the author, it being his birthplace, his boyhood home and where he played his first ball.

"At the time I first appeared upon the scene, the town was in a decidedly embryonic state," he wrote. "Outside of some half-dozen white families that had squatted there, it boasted of no inhabitants save Indians of the Pottawattamie tribe, whose wigwams, or tepees, were scattered here and there upon the prairie and along the banks of the river that then, as now, was not navigable for anything much larger than a flat-bottomed skow.

"The first log cabin that was erected in Marshalltown was built by my father, Henry Anson. He and his father, Warren Anson, his grandfather, Jonathon Anson, and his great-grandfather, Silas Anson, were all born in Duchess county, New York. They were direct descendants of two brothers who came to this country from England sometime in the seventeenth century.

"My mother's maiden name was Jeanette Rice, and she, like my father, was of English descent; so it can be seen how little Swedish blood there is in my veins, in spite of the nickname of 'the Swede', often applied to me during my ball-playing career, which I fancy, was given me more because of my light hair and ruddy complexion than because of any Swedish characteristics. 
"My father homesteaded a tract of land on the site of the present city of Marshalltown, which he laid out and gave the name that it now bears. For a time, it was known as Marshall, being named after the town of Marshall in Michigan, but the syllable 'town' was added and Marshalltown became the name when a post office was applied for and discovery made that already there was a post office of the same name in the state.

\section{Marshalltown's First Whtte Child}

"It was no long after the completion of my father's $\log$ cabin, that I, the first white child born there, came into the world, the exact date of my advent being April 17, 1852. My brother, Sturgis Anson, who is two years my senior, was born at the old home in Michigan, and I had still another brother, Melville, who died while I was yet a small boy."

The town's growth, the increase in white settlers and troubles with the Indians are mentioned. Old Johnny Green, the chief of the Indians at that time, was recalled as remembered by many of Marshalltown's older citizens, and whose skull was believed by the late Dr. Waters to have been unearthed in the excavation made in building the Iowa Soldiers Home.

Anson mentions his school life, and the times he played "hooky" to play "one old cat" and "soak ball," the game of baseball being then in its infancy elsewhere had not yet reached Marshalltown. "When it did come, many a broken window on Main street the Anson family were responsible for," he related.

Can Anson dates the origin of the Marshalltown Base Ball Club as 1866. Capt. Shaw, Emmet Green, A. B. Cooper, Henry and Sturgis, with himself, were given among the list of these promoters, and special attention paid to the greatest game of the club's existence - with Des Moines, in which the players were stationed as follows:

Kinney Williams, pitcher; Emmet Green, catcher; A. B. Cooper, A. C. Anson and Henry Anson on bases; 
Pete Hoskins, short stop; Sam Sager, Sturgis Anson and Milton Ellis in the outfield, with A. J. Cooper, substitute. The game was played in Des Moines, and the victory won by Marshalltown.

The narrative deals extensively with Anson's life with the Chicago league team and its trip around the world, playing with local teams at numerous stopping places and indoctrinating individual players in foreign countries with the intricacies of clever fielding and place hitting. It is illustrated profusely, the frontispiece being a half-tone engraving of the author in his Chicago Uniform. An excellent likeness of Hon. Henry Anson, his father, and the first mayor of Marshalltown, is shown, as also are pictures of Mr. Anson's family and their children, and "Billy" Sunday, with various scenes at places visited by the Chicago club upon its pilgrimages.

A prized exhibit in the Chicago Historical Society's new display is the base ball bat used by Cap. Anson back in 1883 to set an all-times homer record, when he hit five homers in five consecutive times at bat. The display characterized "The National Game" and dramatizes 90 years of professional baseball.

\section{Local Community Weathervanes}

There were those who, without attaining eminence, were the most prominent citizens in the communities in which they lived and were chiefly instrumental in giving character and direction to social and political affairs. Though people unversed in politics seldom realize it, in a representative government these local leaders of public opinion play roles as indispensable as the more distinguished elective and appointive officers. In fact, without the support and encouragement of these local leaders of public opinion high elective officials would be in the position of a general attempting to lead an army into battle without line officers. -Arthur T. Vanderbilt in the South Atlantic Quarterly. 
Copyright of Annals of Iowa is the property of State of Iowa, by \& through the State Historical Society of Iowa and its content may not be copied or emailed to multiple sites or posted to a listserv without the copyright holder's express written permission. However, users may print, download, or email articles for individual use. 